\title{
An Investigation Into the Personal Interaction Items Which Best Explain the Variation in Trust Within Automotive Supply Chains
}

\author{
Aletta Sophia Tolmay, University of South Africa (UNISA), Pretoria, South Africa
}

\begin{abstract}
The sustainability of automotive component suppliers is under threat due to various global challenges. Literature suggests that only the actual personal relationship can differentiate suppliers within supply chains. Literature further encourages more insight into the conceptualization of personal interaction and trust within supply chains. This paper reports on research that tested the importance of trust and its directional linear relationship with personal interaction. Personal interaction revealed a significant correlation with trust, indicating that actions of the Tier 2 supplier during the sourcing process can substantially influence trust with the Tier 1 buyer. It is accordingly crucial for automotive component suppliers to invest in strategies to increase their personal interaction with their buyers in order to promote trust and in turn to promote perceived customer value and customer retention.
\end{abstract}

\section{KEYWORDS}

Automotive Industry, Personal Interaction, Supply Chain Relationships, Trust

\section{INTRODUCTION}

Globally, automotive component suppliers are under pressure from their competition (Barry \& Terry, 2008; Sun, Pan, Wu \& Kuo, 2014, p. 80). The numerous challenges faced by automotive component suppliers include shorter life cycles and more intense global competition (Manzouri, Ab Rahman \& Arshad, 2015, pp. 85-86). Customers also constantly demand more value (Saban \& Luchs, 2011) and lower prices, and they are more knowledgeable (Ambe \& Badenhorst-Weiss, 2011. p. 352). In addition, customers are drastically reducing their supplier numbers in order to foster closer relationships with fewer suppliers (Ambe 2014b, p. 1539; Tolmay 2012, p. 1). Consequently, Tier 2 South African automotive component suppliers (or smaller suppliers lower in the supply chain) find their competitive position threatened and it is therefore crucial that they seek ways to sustain business and to ensure profitability in the long run. As a result of the challenges that this situation presents, automotive supply chain role-players are encouraged to constantly seek solutions to optimize their supply chains and to ensure sustainability (Manzouri et al., 2015, p. 86; Sharma, Bhat, Kumar \& Agarwal, 2017, p. 21).

\section{DOI: 10.4018/IJISSCM.2018040105}

This article published as an Open Access article distributed under the terms of the Creative Commons Attribution License (http://creativecommons.org/licenses/by/4.0/) which permits unrestricted use, distribution, and production in any medium, provided the author of the original work and original publication source are properly credited. 
Tier 2 suppliers provide components to Tier 1 suppliers (or buyers) who, in return, provide modules (complete units such as dashboards) to original equipment manufacturers (OEMs), also known as vehicle manufacturers. This seems to be a global phenomenon, because it is not only the competitive position of South African automotive component suppliers competitive that seems to be under threat: automotive component suppliers globally seem to face similar competitive sustainability challenges (Rugaff \& Sass, 2016, p. 1403). Seeking solutions for this challenge in the South African context might also shed light on possible solutions to be applied by peers globally.

The current commoditized supply chain environment leaves little room for differentiation through price, product quality or logistics (Yeh, 2016, p. 137). It therefore seems that component suppliers are left with only the actual relationship through which to add value and differentiate themselves (Yeh, 2016, p. 137). It is with regard to these supply chain relationships that Tolmay (2017, p. 7) invites more supply chain research within automotive supply chains. Personal interaction is also viewed as an important value enabler and Grönroos (2004, p. 102-103) emphasizes the importance of personal interaction and communication in the day-to-day conducting of business. Yeh (2014, p. 110) supports this and states that higher value results from long-term personal interaction between buyer and seller within automotive supply chains.

Over and above personal interaction, trust can result in differentiation which may ultimately result in customer retention (Çerri, 2012, p. 78-79). Numerous authors report on the importance of trust in supply chain relationships (Cannon, Doney, Mullen \& Petersen, 2010; Çerri, 2012, p. 74; Vieira, Paiva, Finger \& Teixeira, 2013, p. 265). Additionally, various authors have found that higher levels of trust can lead to the retention of customers (Fang, Qureshi, Sun, McCole, Ramsey \& Lim, 2014, p. 408; Saban \& Luchs, 2011, p.47) as well as to commitment and loyalty (Čater \& Čater, 2010, p.1321). Trust, however, is a complex and multifaceted concept and more research in this area is needed (Akrout \& Akrout, 2011, p.2; Yaqub \& Hussain, 2013, p.436). Literature also suggests that more research on trust in the supply chain (Eggert, Ulaga \& Schultz, 2006, p. 20) should be conducted in different countries (Vieira, Paiva, Finger \& Teixeira, 2013, p. 265), such as in South Africa (Ambe, 2014c, p. 279).

This paper investigates collaborative relationships between first and second-tier suppliers (component manufacturers) in the South African automotive supply chains. As personal interaction (Yeh, 2014, p. 110) and trust (Ebrahim-Khanjari, Hopp \& Iravani, 2012, p. 447) have the potential to promote the retention of business in supply chains, the paper aims to address the following research question: "What is the relationship between trust and personal interaction in the automotive supply chain relationship between Tier 1 and Tier 2 suppliers?" Therefore, the objective is to clarify whether personal interaction can be positively correlated with trust. Secondly, if the former statement proves to be true, the paper aims to identify which personal interaction items best explain the variation in trust within the South African automotive supply chains.

The remainder of the article focuses on a review of the relevant literature, the methodology used in the study and the presentation of findings and conclusions.

\section{OVERVIEW OF THE AUTOMOTIVE INDUSTRY}

The automotive industry is one of the largest economic and socioeconomic contributors both globally (Bronkhorst, Steyn \& Stiglingh, 2013, p.1282) and in South Africa (Ambe \& Badenhorst-Weiss, 2013, p.3). The Triad economies of North America, Europe and Japan, although declining, still comprised 42,3 million units (or 48.5\% of global vehicle production) in 2013 (AIEC, 2014, p. 8). Developing countries and regions provide lower-cost manufacturing and huge market growth potential for both the global automotive supply and demand sides and are, as a result, increasingly becoming important industry focus areas (AIEC, 2015, p. 7). Although the South African automotive industry produces less than $1 \%$ of the world's automobiles, it is regarded as a strategic asset for the country (AIEC, 2015, p. 13) as it is the largest manufacturing sub-sector and contributes $7.2 \%$ towards the country's GDP. 
The automotive industry is thus of the utmost importance to the South African economy (Lamprecht, Rudansky-Kloppers \& Strydom, 2011, p. 61; AIEC, 2015, p. 9).

The South African automotive industry is inclusive of a complete supply chain comprising several tiers of suppliers. First, second and third-tier automotive component suppliers provide manufactured components and accessories to OEMs (Lamprecht, 2009, p. 137). First-tier suppliers (also known as sub-assemblers or Tier 1 suppliers) supply components (or modules) directly to the OEMs, while second and third-tier suppliers (Tier 2 and Tier 3 suppliers) provide parts and subcomponents to the first-tier suppliers and also to OEMs (Lamprecht, 2009, p. 137), depending on their requirements. First-tier suppliers are generally large global companies that can capitalize on resources from their parent company, whilst Tier 2 suppliers and other suppliers lower down in the supply chain are generally local South African companies without the valuable global resources of Tier 1 suppliers (Tolmay, 2012, p. 245). Hence, the Tier 1 suppliers represent different cultural backgrounds than do local Tier 2 suppliers and this might account for differences between them as regards management cultures or styles (Ambe, 2014a: p. 47).

South Africa's vehicle manufacturing industry is concentrated in three of the country's nine provinces, namely Gauteng, the Eastern Cape and KwaZulu-Natal, and in close proximity to its suppliers. However, increasingly, some automotive development is also taking place in the Western Cape and North West provinces (AIEC, 2017, p. 22). Six OEMs are represented in South Africa, namely BMW, Ford, Nissan, Volkswagen, Toyota and Mercedes-Benz. As a result, Asian, American and European business cultures are represented within the South African automotive supply chains (Ambe, 2014a: p. 57). Culture, according to Hofstede, Jonker and Meijer (2006: 122), does not necessarily lie in the attributes of individual people, but is rather an attribute of a group that exhibits itself through the behaviours of its members.

The automotive industry faces numerous challenges, such as increased competition (Muneer, Iqbal \& Long, 2014, p. 42; Ambe, 2014b, p. 1539), whilst innovation and quality (Ambe, 2014b, p. 1541), coupled with profitability and supplier retention, are expected to stay intact (Aflaki \& Popescu, 2013, p. 415; Friend, Hamwi \& Rutherford, 2011, p.383). Strategically, many supply chain role-players are also reducing their supplier base (Friend, Hamwi \& Rutherford, 2011, p. 383) in order to maintain long-term relationships with fewer suppliers. As a result, automotive component suppliers are competing for their positions in order to retain business (Friend et al., 2011, p. 383) that will ultimately result in profitability and a competitive advantage.

South African automotive component suppliers also face additional challenges (Ambe, 2014b, p. 1539), including competition from cheap imported products originating from countries such as China and Korea where the costs of manufacturing are low (Kaggwa, 2008, p. 7; Lamprecht, Rudansky-Kloppers \& Strydom, 2011, p. 56), the lack of Tier 2 automotive component supplier performance (Naude \& Badenhorst-Weiss, 2011, p. 279), and limited component design capabilities (Kaggwa, 2008, p. 10).

As quality, pricing and logistics are prescriptive requirements in the automotive supply chain, it is difficult for automotive component suppliers to differentiate on the basis of price or product and service quality. With so little room for differentiation available to them, the only way in which these suppliers can differentiate is by securing long-term relationships with clients (Čater \& Čater, 2010, p. 1321).

In the light of all these challenges, Ambe (2014c, p. 279) states that optimized supplier performance, specifically in the South African automotive supply chain, is a topic that needs to be further investigated. By evaluating supply chain performance, a greater understanding of how to improve supplier performance overall can be created (Ambe, 2014c, p. 279).

Literature suggests that the conceptualization of trust (Akrout \& Akrout, 2011, p. 2), and more specifically the conceptualization of trust within the supply chain, can be expanded (Çerri, 2012, p. 75; Yaqub \& Hussain 2013, p. 436; Eggert et al., 2006, p. 20). Furthermore, since trust in the supply chain is a very complex and multifaceted concept which is viewed differently in different theoretical 
perspectives, Vieira et al. (2013, p. 274), as well as Yaqub and Hussain (2013, p. 436), suggest that more research relating to trust, especially in different countries, is required. Finally, it is also suggested that the influence that certain preceding factors have on trust in the supply chain remains to be investigated (Vieira et al., 2013, p. 274).

Literature further suggests that, in order to create value in the supply chain, trust and the importance thereof, has received some attention (Hemmert, Kim, Kim \& Cho, 2016, p. 25). Personal interaction, however, has been less widely reported on (Rhodes, Lok, Loh \& Cheng, 2016, p. 60). The limitations in the extant literature mentioned above present scope for the investigation of trust and personal interaction in the South African automotive supply chains. Therefore, this paper reflects on how perceived personal interaction influences trust between the Tier 1 (buyer) and Tier 2 suppliers in the South African automotive supply chains. These two constructs (trust and personal interaction) were tested by means of linear regression.

\section{TRUST IN THE SUPPLY CHAIN}

The word 'trust' is often used without considering the actual meaning of the word. In the literature, trust is conceptualized as an assurance of developed reliability and integrity between the customer and the supplier (Gounaris, 2005, p. 127). Gounaris, (2005, p. 127) asserts that " $[t]$ he more the customer trusts the supplier, the higher the perceived value of relationship". Hence, trust increases the likelihood that the customer will remain in the relationship and that increased business will result. According to Dwyer and Oh $(1987$, p. 348) "Trust refers to a party's expectations that another party desires coordination, will fulfil its obligations, and will pull its weight in the relationship". Uslaner (2002, p. 3) views trust and corruption as polar opposites. With soaring corruption levels globally, as well as in South Africa, a lack of trust was found to be a problem in the South African automotive supply chain (Naude \& Badenhorst-Weiss, 2011, p. 93).

With these definitions in mind, trust highlights the importance of confidence on the part of the trusting party. This will result in the trustworthy party being perceived as reliable as well as with a high degree of integrity, which is associated with such qualities as commitment, competence, honesty, fairness, responsibility, helpfulness and benevolence (Morgan \& Hunt, 1994, p. 23).

Literature suggests that trust is of major importance in supply chain relationships (Çerri, 2012, p. 75) and the majority of studies undertaken reveal that trust enhances many advantages in supply chain relationships, for example, increased innovation, supplier performance, sustainability, information and knowledge sharing, customer satisfaction and commitment (Table 1). In the light of these advantages of trust (Table 1), it is important that component suppliers should employ all possible measures to enhance trust within automotive supply chains in order to capitalize on the benefits.

Table 1. Advantages of trust in the supply chain

\begin{tabular}{|l|l|}
\hline \multicolumn{1}{|c|}{ Advantages of Trust } & \multicolumn{1}{c|}{ Author(s) } \\
\hline Increased innovation & Ambe, 2014a; Saban \& Luchs, 2011; Tolmay, 2012; Vieira et al., 2013 \\
\hline Supplier performance & $\begin{array}{l}\text { Akrout \& Akrout, 2011; Ambe, 2014a; Beneke, Adams, Demetriou \& Solomons, 2011, p. } \\
\text { 62; Ebrahim-Khanjari, Hopp \& Iravani, 2012; Saban \& Luchs, 2011; }\end{array}$ \\
\hline Sustainability & Ebrahim-Khanjari, Hopp \& Iravani, 2012, p. 447; Tolmay, 2012 \\
\hline $\begin{array}{l}\text { Information and knowledge } \\
\text { sharing }\end{array}$ & Çerri, 2012; Ebrahim-Khanjari et al., 2012; Saban \& Luchs, 2011; Tolmay, 2012; \\
\hline Customer satisfaction & Çerri, 2012; Saban \& Luchs, 2011; Tolmay, 2012 \\
\hline Commitment & Li, Ford, Zhai \& Xu, 2012; Saban \& Luchs, 2011; Tolmay, 2012; Vieira et al., 2012 \\
\hline
\end{tabular}


Literature promises that trusting supply chain relationships ultimately result in retention of business (Fang et al., 2014, p. 408; Saban \& Luchs, 2011, p. 47). Trust also contains an element of risk and, in general, risky activities with untrustworthy individuals or organizations will be avoided (Uslaner, 2013, p. 630). Trust is therefore viewed as a key factor in long-term relationships between partners in the supply chain (Vieira et al., 2013, p. 266). Vieira et al. (2013, p. 266) argue that trust involves at least two parties, namely a trustor and a trustee, which will be referred to in this study as the Tier 1 customer (trustor) and Tier 2 suppliers (trustees) respectively.

However, Hofstede, Jonker and Meijer (2006:122) state that trust relates to culture and is not an attribute of individual people. They also state that there is differentiation between intrinsic and enforceable trust. Intrinsic trust, according to Hofstede et al. (2006: 124), refers to trust that accepts vulnerability, whilst enforceable trust implies trust in good performance that is backed up by the perception of the trustor resulting in reward or punishment for the trustee. It seems that enforceable trust is applicable in automotive supply chains as the trustor (customer) will suspend its contract with the supplier in the absence of performance and that such suspension will be seen as the punishment. On the contrary, the supplier (trustee) is rewarded through a long-term contract if it performs.

In recent times, trust appears to have been diminishing within the South African economy with the government also increasingly being viewed as corrupt (David, Soni \& Asmal, 2016: p. 62). However, this might not be true in the supply chain environment and this paper therefore aims to determine whether this holds true within the South African automotive supply chain culture.

Apart from trust, literature also suggests that personal interaction has the potential to lead to differentiation within supply chains (Yeh, 2014, p. 110).

\section{PERSONAL INTERACTION WITHIN THE SUPPLY CHAIN}

Within supplier-buyer relationships, personal interaction is viewed as an important value enabler (Grönroos, 2004, pp. 102-103; Ulaga \& Eggert, 2006, p. 125) as well as a differentiator (Yeh, 2016, p. 137).

The key to supply chain management is to recognize the importance and prominence of longterm supplier relationships (Ambe, 2014a, p.47; Li, Ford, Zhai \& Xu, 2012, p. 5447). Therefore, the manufacturing supply chains (and by implication the automotive supply chains) are characterized by the inclination to forge strong long-term relationships with fewer suppliers (Cadden, Marshall \& Cao, 2013, p. 87). In the light of the current trend of working with fewer suppliers, supply chain buyers nowadays seem to utilize the value of determining whether to maintain, develop or divest in supplier relations (Yeh, 2014, p. 109).

The aim of personal interaction is to create value (Eggert et al., 2006, p. 26; Ulaga \& Eggert, 2006, pp. 134-135). Apart from being a value creator, personal interaction enhances good working relationships which, in turn, result in sustainability and close interaction between buyer and seller within the supply chain (Rhodes et al., 2016, p. 67). As a result, personal interaction can further be viewed as a relational benefit and adds value during the sourcing process (Eggert et al., 2006, p. 21).

Ulaga and Eggert (2006, p. 123) state that personal interaction relates to the fact that the supplier should be in regular and personal contact with personnel of the customer (buyer) and maintain good working relationships with management on all levels. Therefore, personal interaction is associated with good personal relationships, with the provision of valuable advice and with problem-solving, and is viewed as important in different national contexts (Wuyts, Verhoef \& Prins, 2009, p. 42). Eggert et al. (2006, p. 21) visualize personal interaction as the display of efficient communication and problem-solving abilities, and working towards mutual goals with the customer.

Eggert et al. (2006, p. 26) as well as Ulaga and Eggert (2006, p. 134-135) suggest that suppliers who wish to sustain business with their buyers (or customers) should pay attention 
to personal interaction as a strategic approach. Chen and Lin (2011, pp. 32-33) affirm that relational benefits originate from personal interaction, and Tolmay (2017, p. 3) supports this view for the South African automotive supply chains and encourages personal interaction as a value enabler.

Rhodes et al. (2016, p. 65) confirm that customers and suppliers do not trade solely on the exchange of goods and services, and they state that there are other social elements, such as personal interaction, that make one service provider more attractive than the other. Unfortunately, the practice of personal interaction with suppliers has largely been ignored and the associated benefits have been lost (Rhodes et al., 2016, p. 60). Furthermore, although trust and personal interaction have been investigated in past studies, there is still a paucity of literature in which these constructs are clearly conceptualized within supply chains (Rhodes et al., 2016, p. 60). With these limitations in mind, the aim of this article is to enhance the conceptualization of personal interaction and trust within the South African automotive supply chains. The correlation between personal interaction and trust within the South African automotive supply chains was tested by means of linear regression.

\section{RESEARCH METHODOLOGY}

As part of a larger study, a quantitative research methodology was followed and the questionnaire for the research was based on the seminal Key Mediating Variable (KMV) work of Morgan and Hunt (1994) relating to trust (Table 3). The questions relating to trust were obtained from the research conducted by Morgan and Hunt (1994, p. 35). One of the questions from Morgan and Hunt (1994: 35) was adapted from a negative statement to a positive statement as follows: "In our relationship with supplier A, our firm feels that Supplier A can be trusted".

The questions relating to personal interaction were obtained from the prominent study of Eggert et al. (2006) (Table 3). However, the number of personal interaction items was reduced from seven to four with the aim of compiling a shorter questionnaire and preventing duplication (Table 3). In total, seven closed-ended questions were included, each utilizing a bipolar seven-point semantic-differential scale where respondents had to choose their perception of a statement relating to their best supplier (Supplier A). The respective respondents had to indicate their perception from "strongly disagree" to "strongly agree".

In preparation for the research, a questionnaire validation process was conducted with industry experts in the South African automotive supply chain. The purpose of this process was to determine whether the questions were applicable to the South African automotive supply chain context and to identify additional constructs unique to the context. Following the finalization of the questionnaire, an email invitation containing a link to the web-based survey hosted by SurveyMonkey was sent to respondents. Those who did not respond were contacted telephonically to encourage them to participate in the research.

The survey targeted managers from Tier 1 suppliers in the South African automotive supply chain, all of them members of the National Association of Allied and Automotive Component Manufacturers (NAACAM). Emails were forwarded to all managers listed in the NAACAM membership list, representing a total of 140 managers. This membership list of managers therefore constituted the sampling frame. The survey requested managers to indicate their designation as either: CEO/Senior manager, Technical manager or Administrative/Procurement manager.

\section{RESEARCH FINDINGS}

The respondents' profiles are presented, followed by the analysis of the relationships between trust and personal interaction. 


\section{Profile of Respondents}

The responses suggested that decision makers in Tier 1 automotive component manufacturers in South Africa were thoroughly represented (see Table 2 for a summary of respondent profiles).

Most respondents (about 71\%) had some form of international shareholding. Most respondents were from fairly large companies, with about $78 \%$ representing companies with a turnover of more than R50 million per annum, and almost $89 \%$ having more than 50 employees. Respondents were concentrated in the major car manufacturing regions of Gauteng (47\%), the Eastern Cape (32\%) and the Western Cape (11\%).

Respondents were mostly senior decision makers, with more than half at CEO or senior manager level, about $38 \%$ were procurement decision-makers and $10 \%$ technical managers.

In general, a good representation was obtained and a total of 114 (out of a possible 140) responses were received. This represents a very high response rate of $81.4 \%$.

\section{Analysis of the Relationship Between Personal Interaction and Trust}

The research aimed to test the directional correlation between personal interaction and trust in the South African automotive supply chains and a linear regression model was therefore employed.

Table 2. Profile of respondents

\begin{tabular}{|c|c|c|c|}
\hline \multicolumn{2}{|r|}{ Profile } & $\mathbf{n}$ & $\%$ \\
\hline \multirow{4}{*}{ Shareholding } & Local shareholding & 31 & $29.2 \%$ \\
\hline & International shareholding & 47 & $44.3 \%$ \\
\hline & Mixture - local and international shareholding & 28 & $26.4 \%$ \\
\hline & Total & 106 & \\
\hline \multirow{5}{*}{ Company turnover } & R0 - R5 million & 5 & $5.0 \%$ \\
\hline & $>$ R5 million - R50 million & 17 & $16.8 \%$ \\
\hline & $>$ R50 million - R200 million & 25 & $24.7 \%$ \\
\hline & $>$ R200 million & 54 & $53.5 \%$ \\
\hline & Total & 101 & \\
\hline \multirow{5}{*}{ Employees } & $1-20$ employees & 2 & $1.9 \%$ \\
\hline & $21-50$ employees & 10 & $9.3 \%$ \\
\hline & $51-200$ employees & 40 & $37.4 \%$ \\
\hline & >200 employees & 55 & $51.4 \%$ \\
\hline & Total & 107 & \\
\hline \multirow{5}{*}{ Province } & Gauteng & 49 & $46.7 \%$ \\
\hline & KwaZulu-Natal & 10 & $9.5 \%$ \\
\hline & Eastern Cape & 34 & $32.4 \%$ \\
\hline & Western Cape & 12 & $11.4 \%$ \\
\hline & Total & 105 & \\
\hline \multirow{4}{*}{ Position } & $\mathrm{CEO} /$ Senior manager & 51 & $52.0 \%$ \\
\hline & Technical manager & 10 & $10.2 \%$ \\
\hline & Administrative Procurement manager & 37 & $37.8 \%$ \\
\hline & Total & 98 & \\
\hline
\end{tabular}


Preceding the linear regression, an exploratory factor analysis (EFA) was included in the data analysis to explore the interrelationships among a set of variables/items and also to confirm the underlying factor structure (Pallant, 2011, p. 181).

Firstly, principal component analyses were conducted, using principal component extraction and Varimax rotation, to determine the unidimensionality of each of the constructs 'trust' and 'personal interaction' as represented in the questionnaire. The rotated solution revealed the presence of a simple structure (Thurstone, 1947), with each of the two constructs revealing strong loadings (Table 3). The Varimax rotation method was utilized since it results in a clearer separation of factors (Pallant, 2011, p. 185). For the extraction method, the set of items was subjected to Principle Axis Factoring (PAF) using SPSS18.0 software to extract the communalities.

A preliminary analysis was performed to ensure that there were no violations of the assumptions of normality, linearity and homoscedasticity. The inspection of the correlation matrix revealed the presence of many coefficients of 0.5 and higher, motivating the sustainability for factor analysis. The Kaiser-Meyer-Olkin Measure of Sampling Adequacy was 0.906 and 0.898 for trust and personal interaction, respectively. The Bartlett's Test of Sphericity was significant $(\mathrm{p}<0.001)$ for both constructs, indicating that factor analysis was appropriate in each case.

The analyses confirmed unidimensionality for both trust and personal interaction (sourcing process). The analyses identified only one factor in each case, based on the eigenvalue criterion (eigenvalue greater than 1). The factor loadings of trust and personal interaction are shown in Table 3 , and the single factors, respectively, explain $37.31 \%$ of variance in the trust scale and $17.90 \%$ of variance in the personal interaction scale.

Table 3. Construct scales for trust and personal interaction

\begin{tabular}{|c|c|c|c|c|c|c|c|}
\hline Constructs & Questions & $\begin{array}{l}\text { Factor } \\
\text { Loadings }\end{array}$ & $\begin{array}{l}\text { Cronbach's } \\
\text { Alpha for } \\
\text { Construct }\end{array}$ & $\begin{array}{l}\text { Mean of } \\
\text { Individual } \\
\text { Items }\end{array}$ & $\begin{array}{c}\text { Std. } \\
\text { Dev. for } \\
\text { Individual } \\
\text { Items }\end{array}$ & $\begin{array}{l}\text { Factor } \\
\text { Mean }\end{array}$ & $\begin{array}{l}\text { Std. } \\
\text { Dev. } \\
\text { for } \\
\text { Factor }\end{array}$ \\
\hline \multirow{4}{*}{$\begin{array}{l}\text { Personal } \\
\text { Interaction }\end{array}$} & $\begin{array}{l}\text { Supplier A has the } \\
\text { ability to provide us with } \\
\text { appropriate information. }\end{array}$ & 0.745 & \multirow{4}{*}{0.904} & 5.842 & 1.001 & \multirow{4}{*}{5.697} & \multirow{4}{*}{0.968} \\
\hline & $\begin{array}{l}\text { Supplier A has the ability } \\
\text { to give us a feeling } \\
\text { of being treated as an } \\
\text { important client. }\end{array}$ & 0.740 & & 5.728 & 1.131 & & \\
\hline & $\begin{array}{l}\text { Supplier A offers good } \\
\text { working relationships. }\end{array}$ & 0.703 & & 5.779 & 1.041 & & \\
\hline & $\begin{array}{l}\text { Supplier A has the ability } \\
\text { to provide general know- } \\
\text { how. }\end{array}$ & 0.588 & & 5.434 & 1.217 & & \\
\hline \multirow{3}{*}{ Trust } & $\begin{array}{l}\text { In our relationship, my } \\
\text { firm feels that Supplier A } \\
\text { can be counted on to do } \\
\text { what is right. }\end{array}$ & 0.906 & \multirow{3}{*}{0.917} & 5.786 & & \multirow{3}{*}{5.866} & \multirow{3}{*}{0.929} \\
\hline & $\begin{array}{l}\text { In our relationship with } \\
\text { Supplier A, our firm feels } \\
\text { that Supplier A can be } \\
\text { trusted. }\end{array}$ & 0.938 & & 5.939 & & & \\
\hline & $\begin{array}{l}\text { In our relationship, } \\
\text { Supplier A demonstrates } \\
\text { a high level of integrity. }\end{array}$ & 0.935 & & 5.800 & & & \\
\hline
\end{tabular}


In testing for internal consistency (reliability), Cronbach's Alpha coefficient for trust and personal interaction was found to be 0.917 and 0.904 , respectively. Both these values are deemed highly satisfactory as the acknowledged threshold of 0.7 was exceeded (Table 3) (Pallant, 2011, p. 6). This suggests that there is agreement amongst respondents regarding personal interaction and trust within the South African automotive supply chains.

Subsequently, the factor scores were calculated as the mean score of the variables included in each factor. The descriptive statistics for the factor-based scores of trust and personal interaction reveal that the standard deviations are similar. The mean scores of these constructs were higher than 5 for both trust $($ Mean $=5.86)(\mathrm{SD}=0.93)$, and personal interaction $($ Mean $=5.70)(\mathrm{SD}=0.97)$, indicating relatively high levels of trust and personal interaction.

The skewness values (trust -.86 and personal interaction -1.15) and kurtosis values (trust 1.13 and personal interaction 3.71) for the two constructs do not show deviations from normality (Table 4).

Thereafter, a linear regression was utilized to evaluate the directional relationship between the independent variable (personal interaction) with the dependent variable (trust) $($ Std. beta $=0.972$ ) $(\mathrm{p}<0.01)$. The regression results are presented in Table 5.

It was found that personal interaction revealed a significant correlation with trust, indicating that actions from the Tier 2 supplier during the sourcing process can substantially influence trust with the Tier 1 buyers. Therefore, the regression model reveals that personal interaction is a strong, positive, statistically significant predictor of trust at the $1 \%$ level of statistical significance. This might suggest that trust and personal interaction are seen as highly relevant in the South African automotive supply chains. Although the South African economy and business culture are generally seen as being untrustworthy (David et al., 2016: p. 62), this finding (Table 5) might suggest that the South African automotive supply chains highly value trust brought about through personal interaction, irrespective of cultural background.

Table 4. Statistics - trust, and personal interaction $(n=114)$

\begin{tabular}{|l|l|l|}
\hline \multicolumn{1}{|c|}{ Construct } & \multicolumn{1}{c|}{ Trust } & \multicolumn{1}{c|}{ Personal Interaction } \\
\hline Mean & 5.86 & 5.70 \\
\hline Std. Deviation & .93 & .97 \\
\hline Skewness & -.86 & -1.15 \\
\hline Kurtosis & 1.13 & 3.71 \\
\hline Minimum & 2.33 & 1.00 \\
\hline Maximum & 7.00 & 7.00 \\
\hline
\end{tabular}

Table 5. Regression model - Personal interaction and trust

\begin{tabular}{|l|l|}
\hline \multicolumn{2}{|l|}{ Regression model (dependent variable $=$ trust, independent variable $=$ personal interaction) } \\
\hline $\begin{array}{l}\text { Standardized Beta (personal interaction) } \\
\text { Trust }(p \text { value) }\end{array}$ & $0.792\left(.000^{* *}\right)$ \\
\hline F $(p$ value $)$ & $188.997\left(.000^{* *}\right)$ \\
\hline R Square & 0.628 \\
\hline Note: ${ }^{*} p<0.05,{ }^{* *} p<0.01$ &
\end{tabular}


Following the first linear regression analysis, the secondary aim of the research was to determine which of the personal interaction items had the highest correlation with trust. Coefficients for item $\mathrm{i}$ $($ Sig. $=.828)$ and iv (Sig. $=.278)$ were statistically nonsignificant (refer to Table 6). In contrast, item ii and iii were significant (Sig. = .000) (refer to Table 6). Item iii, namely; "Supplier A offers good working relationships" reported the highest standardized beta $(0.439$; Sig. $=.000)$, followed by item ii; "Supplier A has the ability to give us a feeling of being treated as an important client" (Std. Beta $=.341 ;$ Sig. $=.000)($ Table 6$)$.

In line with this finding, it appears that the Tier 1 suppliers (customers) place a lot of value on the actual working relationships they have with their suppliers and that they appreciate being treated well. With this emphasis on the actual working relationships within the South African automotive supply chain, a conclusion and recommendations will be formulated in the next section.

\section{CONCLUSION AND RECOMMENDATIONS}

This paper reports on research that investigated the collaborative relationships between first and secondtier suppliers (component manufacturers) in the South African automotive supply chains. The Tier 2 South African automotive component suppliers are under pressure in the global arena due to various factors, such as the reduction of suppliers, cost reduction and constant added-value requirements, all of which affects their sustainability. With little room for differentiation through quality and price, Tier 2 suppliers are left only with the actual supplier relationship to add value in the supply chain.

Literature suggests that personal interaction as part of the sourcing process (Eggert, et al., 2006, p. 24), along with trust, can greatly enhance supplier relationships and result in customer retention. However, in existing literature, it is not always clear what the respective roles of personal interaction and trust are with regard to the supply chain. Therefore, more research relating to personal interaction and trust within supply chains is encouraged by the literature. The research question reported on in this paper was: "What is the relationship between trust and personal interaction in the automotive supply chain relationship between Tier 1 and Tier 2 suppliers?" Secondly, the paper aimed to determine which personal interaction items best explains the variation in trust.

By means of a linear regression analysis it was revealed that personal interaction is a strong, positive, statistically significant predictor of trust. This indicates that personal interaction on the part of the Tier 2 supplier during the sourcing process can substantially influence trust with Tier 1 customers. Previous studies have alluded to the fact that trust might be deteriorating in South African automotive supply chains (Naude \& Badenhorst-Weiss, 2011, p. 93). However, this study suggests that trust is highly valued within the South African automotive supply chains, specifically between first and second tier suppliers, notwithstanding their cultural backgrounds. Although Tier 2 suppliers are mainly of local origin, and Tier 1 suppliers represent diverse international cultures, it seems that the relationship between these two tiers of suppliers is built on trust.

Table 6. Personal interaction items

\begin{tabular}{|l|l|l|l|}
\hline \multicolumn{1}{|c|}{ Item No. } & \multicolumn{1}{c|}{\begin{tabular}{c}
\multicolumn{1}{c|}{ Item } \\
Personal Interaction
\end{tabular}} & $\begin{array}{c}\text { Standardized } \\
\text { Beta Coefficient }\end{array}$ & \multicolumn{1}{c|}{ Sig. } \\
\hline i & $\begin{array}{l}\text { Supplier A has the ability to provide us with appropriate } \\
\text { information. }\end{array}$ & 0.022 & 0.828 \\
\hline ii & $\begin{array}{l}\text { Supplier A has the ability to give us a feeling of being treated as } \\
\text { an important client. }\end{array}$ & 0.341 & 0.000 \\
\hline iii & Supplier A offers good working relationships. & 0.439 & 0.000 \\
\hline iv & Supplier A has the ability to provide general know-how. & 0.096 & 0.278 \\
\hline
\end{tabular}


Following the linear regression analysis, the secondary aim of the research was to determine which personal interaction items best explain the variation in trust. Coefficients for two items were statistically not significant, namely; "Supplier A has the ability to provide us with appropriate information", and Supplier A has the ability to provide general know-how". In contrast, two items were significant, namely "Supplier A offers good working relationships", which reported the highest standardized beta, followed by "Supplier A has the ability to give us a feeling of being treated as an important client". The latter item revealed the strongest variation in trust.

It seems that Tier 1 suppliers would like to be treated as being important and enjoy good working relationships with their suppliers. It is therefore suggested that Tier 2 suppliers that wish to sustain business in the supply chain should strategically pay attention to personal interaction as it directly results in trust. Personal attention to customers (Tier 1 suppliers) appears to be strategically important for Tier 2 suppliers and, therefore, this aspect should be given the necessary attention. In order to add value through personal interaction, Tier 2 suppliers are advised to be in regular personal contact with buyers and to maintain good working relationships with management on all levels (Ulaga and Eggert, 2006, p. 123).

Contrary to the belief that stakeholders in the South African economy might be untrustworthy (David et al., 2016: p. 62), this research suggests that trust is highly valued within the South African automotive supply chains between first and second tier suppliers. Although various assumptions are made with regard to corruption in the South African context, it seems that the South African automotive supply chains might be an exception to this rule.

Trust brought about through personal interaction is highly regarded in long-term supplier relations. Therefore, the implementation of a strategy to enhance trust (which promises business retention) through personal interaction, specifically driven by good working relationships within the South African automotive supply chain, is highly recommended. Global peers might take note of this as the same phenomenon might also affect their business sustainability.

This paper makes a valuable contribution towards the conceptualization of personal interaction and trust within the South African (and arguably global) automotive supply chains. However, it also offers several opportunities for further research.

The respondents in the current research indicated the perspectives of three role-players, namely the company CEO, the technical manager and the procurement manager. Since the results of the current research focused on the collective response, it would be insightful to analyse different viewpoints on trust and personal interaction from each of these different functional categories and to determine how their viewpoints differ (if at all) from one another.

Owing to the fact that the study addressed only the viewpoint of Tier 1 buyers (customers) as to what they require from their best Tier 2 suppliers, it would be interesting to investigate the converse, namely what Tier 2 suppliers require from their Tier 1 customers. These matching requirements could result in better supply chain management and it would also be interesting to filter this study down the supply chain and determine the relationship between suppliers lower down in the chain.

Culture plays a crucial role in the automotive supply chain. More research is required on the different cultural requirements with regard to trust and personal interaction. Supply chain role players have a range of different backgrounds and approaches and will thus differ on how to relate to the different cultures in play. This research might be applied to supply chains in other countries to test the findings. Since the current research focused only on trust and personal interaction between Tier 1 and Tier 2 suppliers in the South African automotive supply chain, a similar study could be undertaken between the OEM and the independent aftermarket role players, such as automotive dealers. These two role players have different shareholdings, objectives and values, and their interaction is often characterized by conflict. 
To conclude, in the light of extreme global pressure, the survival of South African component suppliers in the automotive supply chain rests upon personal interaction which might directly influence trust with the aim of retaining business.

\section{ACKNOWLEDGMENT}

This article is based on the doctoral thesis of A.S.T. (University of South Africa). A.S.T. was the main researcher who originally conceptualized the article. A consultant, Dr Dion van Zyl assisted with additional statistical data analysis and interpretation. This research received no specific grant from any funding agency in the public, commercial, or not-for-profit sectors. 


\section{REFERENCES}

Aflaki, S., \& Popescu, I. (2013). Managing retention in service relationships. Management Science, 60(2), 415-433. doi:10.1287/mnsc.2013.1775

AIEC. (2014). Automotive export manual 2014. Pretoria: Zest (Pty) Ltd. Pretoria. ISBN 978-0-620-59887-6.

AIEC. (2015). Automotive export manual 2015. Pretoria: Zest (Pty) Ltd. Pretoria. ISBN 978-0-620-65335-0.

AIEC. (2017). Automotive export manual 2017. Pretoria: Zest (Pty) Ltd. Pretoria. ISBN:978-0-620-75568-9.

Akrout, W., \& Akrout, H. (2011). Trust in B-to-B: Toward a dynamic and integrative approach. Recherche et Applications en Marketing, 26(1), 1-21. doi:10.1177/205157071102600101

Ambe, I. M. (2014). Determining supply chain practices of vehicle manufacturers in South Africa. Journal of Contemporary Management, 11, 47-61.

Ambe, I. M. (2014). Difficulty to overcome supply chain challenges faced by vehicle manufacturers in South Africa. Journal of Applied Business Research, 30(5), 1539-1550. doi:10.19030/jabr.v30i5.8806

Ambe, I. M. (2014). Key Indicators for Optimising supply chain performance: The case of light vehicle manufacturers in South Africa. Journal of Applied Business Research, 30(1), 277-290. doi:10.19030/jabr. v30i1.8301

Ambe, I. M., \& Badenhorst-Weiss, J. A. (2011). South African automotive industry: Trends and challenges in the supply chain. Journal of Contemporary Management, 8, 337-362.

Ambe, I. M., \& Badenhorst-Weiss, J. A. (2013). Challenges of locally manufactured vehicle supply chains in South Africa. Journal of Transport and Supply Chain Management, 7(1), 1-8. doi:10.4102/jtscm.v7i1.100

Barry, J., \& Terry, T. S. (2008). Empirical study of relationship value in industrial services. Journal of Business and Industrial Marketing, 23(4), 228-241. doi:10.1108/08858620810865807

Beneke, J., Adams, E., Demetriou, O., \& Solomons, R. (2011). An exploratory study of the relationship between store image, trust, satisfaction and loyalty in a franchise setting. Southern African Business Review, 15(2), 59-74.

Bronkhorst, E., Steyn, J., \& Stiglingh, M. (2013). The Automotive Production and Development Programme: An analysis of the opinions of South African stakeholders. Journal of Applied Business Research, 29(5), 1281-1300. doi:10.19030/jabr.v29i5.8013

Cadden, T., Marshall, D., \& Cao, G. (2013). Opposites attract: Organisational culture and supply chain performance. Supply Chain Management, 18(1), 86-103. doi:10.1108/13598541311293203

Cannon, J. P., Doney, P. M., Mullen, M. R., \& Petersen, K. J. (2010). Building long-term orientation in buyersupplier relationships: The moderating role of culture. Journal of Operations Management, 28(6), 506-521. doi:10.1016/j.jom.2010.02.002

Čater, T., \& Čater, B. (2010). Product and relationship quality influence on customer commitment and loyalty in B2B manufacturing relationships. Industrial Marketing Management, 39(8), 1321-1333. doi:10.1016/j. indmarman.2010.02.006

Çerri, S. (2012). Exploring factors affecting trust and relationship quality in a supply chain context. Journal of Business Studies, 4, 9-90.

Chen, T. Y., \& Lin, F. J. (2011). Using relationship norms to create appropriate relationship value: Evidence from the credit card industry. Journal of Relationship Marketing, 10(1), 28-42. doi:10.1080/15332667.2011.549006

David, J. E., Soni, P., \& Asmal, R. (2016). Downgrade and junk status looms on the horizon for the South African Economy: Finance Minister in a no win situation as toxic politics takes center stage. International Journal of Accounting Research, 2(11), 50-90. doi:10.12816/0028139

Dwyer, F. R., \& Oh, S. (1987). Output sector munificence effects on the internal political economy of marketing channels. JMR, Journal of Marketing Research, 24(4), 347-358. doi:10.2307/3151382 
Ebrahim-Khanjari, N., Hopp, W., \& Iravani, S. M. R. (2012). Trust and information sharing in supply chains. Production and Operations Management Society, 21(3), 444-464. doi:10.1111/j.1937-5956.2011.01284.x

Eggert, A., Ulaga, W., \& Schultz, F. (2006). Value creation in the relationship life cycle: A quasi-longitudinal analysis. Industrial Marketing Management, 35(1), 20-27. doi:10.1016/j.indmarman.2005.07.003

Fang, Y., Qureshi, I., Sun, H., McCole, P., Ramsey, E., \& Lim, K. H. (2014). Trust, satisfaction, and online repurchase intention: The moderating role of perceived effectiveness of e-commerce institutional mechanisms. Management Information Systems Quarterly, 38(2), 407-427. doi:10.25300/MISQ/2014/38.2.04

Friend, S. B., Hamwi, G. A., \& Rutherford, B. N. (2011). Buyer-seller relationships within a multisource context: Understanding customer defection and available alternatives. Journal of Personal Selling \& Sales Management, 31(4), 383-395. doi:10.2753/PSS0885-3134310402

Gounaris, S. (2005). Trust and commitment influences on customer retention: Insights from business to business services. Journal of Business Research, 58(2), 126-140. doi:10.1016/S0148-2963(03)00122-X

Grönroos, G. (2004). The relationship marketing process: Communication, interaction, dialogue, value. Journal of Business and Industrial Marketing, 19(2), 99-113. doi:10.1108/08858620410523981

Hemmert, M., Kim, D., Kim, J., \& Cho, B. (2016). Building the supplier's trust: Role of institutional forces and buyer firm practices. International Journal of Production Economics, 180, 25-37. doi:10.1016/j.ijpe.2016.05.023

Hofstede, G., Jonker, C., Meijer, S. \& Verwaart, T. (2006). Modelling trade and trust across cultures. Trust Management, 120-134.

Kaggwa, M. (2008). Modelling South Africa's incentives under the Motor Industry Development Programme. Unpublished $\mathrm{PhD}$ thesis, University of Pretoria, Pretoria.

Lamprecht, N. (2009). The impact of the Motor Industry Development Programme (MIDP) on the export strategies of the South African light motor vehicle manufacturers (1995-2008). Unpublished DCom thesis, University of South Africa, Pretoria.

Lamprecht, N., Rudansky-Kloppers, S., \& Strydom, J. W. (2011). South African automotive policy intervention (1924-2008): The case of an intelligently designed automotive support structure. Journal of Contemporary Management, 8, 54-75.

Li, L., Ford, J. B., Zhai, X., \& Xu, L. (2012). Relational benefits and manufacturer satisfaction: An empirical study of logistics service in supply chain. International Journal of Production Research, 50(19), 5445-5459. doi:10.1080/00207543.2011.636388

Manzouri, M., Ab Rahman, M. N., \& Arshad, H. (2015). Issues in supply chain implementation: A comparative perspective. International Journal of Information Systems and Supply Chain Management, 8(1), 85-101. doi:10.4018/ijisscm.2015010105

Morgan, R. M., \& Hunt, S. D. (1994). The commitment-trust theory of relationship marketing. Journal of Marketing, 58(3), 20-38. doi:10.2307/1252308

Muneer, S., Iqbal, S. M. J., \& Long, C. S. (2014). An incorporated structure of perceived organizational support, knowledge-sharing behavior, organizational trust and organizational commitment: A strategic knowledge management approach. Pakistan Journal of Commerce and Social Sciences, 8(1), 42-57.

Naudé, M.J., \& Badenhorst-Weiss, J.A. (2011). The effect of problems on supply chain wide efficiency. Journal of transport and supply chain management, 5(1), 278-298.

Pallant, J. (2011). SPSS Survival Manual 4th edition: A step by step guide to data analysis using SPSS version 18. Maidenhead, Berkshire: Open University Press.

Rhodes, J., Lok, P., Loh, W., \& Cheng, V. (2016). Critical success factors in relationship management for services outsourcing. Service Business, 10(1), 59-86. doi:10.1007/s11628-014-0256-8

Rugraff, E., \& Sass, M. (2016). How did the automotive component suppliers cope with the economic crisis in Hungary? Europe-Asia Studies, 68(8), 1396-1420. doi:10.1080/09668136.2016.1221062 
Saban, K. A., \& Luchs, R. (2011). The benefits of governing with a trust-centric strategy. Journal of Leadership, Accountability and Ethics, 8(3), 43-55.

Sharma, S. K., Bhat, A., Kumar, V., \& Agarwal, A. (2017). Path analysis model for supply chain risk management. International Journal of Information Systems and Supply Chain Management, 10(2), 21-41. doi:10.4018/ IJISSCM.2017040102

Sun, P. C., Pan, F. T., Wu, P. C., \& Kuo, C. C. (2014). An empirical study of B2B relationship value offering type as a moderator. Journal of Business Studies Quarterly, 6(1), 79-97.

Thurstone, L. L. (1947). Multiple factor analysis. Chicago: University of Chicago Press.

Tolmay, A. (2012). Developing a relationship value model for the South African business to business automotive supply chain. Unpublished DBL thesis, University of South Africa, Pretoria.

Tolmay, A.S. (2017). The correlation between relationship value and business expansion in the South African automotive supply chains. Journal of Transport and Supply Chain Management, (11), 1-8.

Ulaga, W., \& Eggert, A. (2006). Value-based differentiation in business relationships: Gaining and sustaining key supplier status. Journal of Marketing, 70(1), 119-136. doi:10.1509/jmkg.2006.70.1.119

Uslaner, E. M. (2002). The moral foundations of trust. UK: Cambridge University Press. doi:10.1017/ CBO9780511614934

Uslaner, E. M. (2013). Trust as an alternative to risk. Public Choice, 157(3-4), 629-639. doi:10.1007/s11127013-0082-x

Vieira, L. M., Paiva, E. L., Finger, A. B., \& Teixeira, R. (2013). Trust and supplier-buyer relationships: An empirical analysis. BAR, Rio de Janeiro, 10(3/2), 263-280.

Wuyts, S., Verhoef, P. C., \& Prins, R. (2009). Partner selection in B2B information service markets. International Journal of Research in Marketing, 26(1), 41-51. doi:10.1016/j.ijresmar.2008.07.008

Yaqub, M. Z., \& Hussain, D. (2013). How do the relational investments affect relational outcomes? Journal of Applied Business Research, 29(2), 433-442. doi:10.19030/jabr.v29i2.7648

Yeh, Y. P. (2014). The Impact of relational governance on relational exchange performance: A case of the Taiwanese automobile industry. Journal of Relationship Marketing, 13(2), 108-124. doi:10.1080/15332667.2 014.910074

Yeh, Y. P. (2016). Critical influence of relational governance on relationship value in strategic supply management. European Business Review, 28(2), 137-154. doi:10.1108/EBR-09-2014-0068

Aletta Sophia Tolmay is a senior lecturer in the subject of production and operations management within the Department Operations Management at the University of South Africa (UNISA). Before joining UNISA, Dr A Tolmay worked in various sectors including automotive, ICT, consulting and local government. Dr Tolmay is extensively involved in research regarding supply chain relating to the automotive industry. She is also extensively involved with research in the South African automotive industry regarding worldwide export statistics and trends. 